\title{
High Quality Oil Recovery from Oil Sludge Employing a Pyrolysis Process with Oil Sludge Ash Catalyst
}

\author{
Shuo Cheng ${ }^{1 *}$, Aimin $\mathrm{Li}^{2}$ and Kunio Yoshikawa ${ }^{1}$
}

${ }^{1}$ Department of Environmental Science and Technology, Tokyo Institute of Technology, Japan

${ }^{2}$ School of Environmental Science and Technology, Dalian University of Technology, China

\begin{abstract}
In this study, pyrolysis experiments of two kinds of oil sludge were conducted using a bench-scale fixed bed reactor, which is mainly consisted of a pyrolyzer and a reformer reactor. The effects of the pyrolysis method and the catalysts on the yield and quality of oil products obtained from pyrolysis of oil sludge were investigated. Characterization of the oil products was preliminary judged by comparing their distillation results with the diesel standard and the oil product without catalyst usage. Then, the chemical characterization of a part of the pyrolytic oil was conducted by FT-IR and NMR analysis. In the last step of these experiments, the oil products obtained from pyrolysis of oil sludge with the use of oil field sludge ash and oil tank sludge ash as catalysts were mixed with diesel oil by the volume ratio of one-to-five and one-to-ten. The fuel characteristic of the oil mixtures was identified from the point of the viscosity, the density, the cetane index, the carbon number distribution and the higher heating value $(\mathrm{HHV})$. The results of experiment show that the highest oil product yield was obtained at the one-stage pyrolysis of the oil field sludge and also the oil tank sludge with the oil field sludge ash as the catalyst. According to the results of NMR analysis, the main part of the carbon in the oil product from pyrolysis of the oil sludge with the oil sludge ash was aliphatic carbon. The total ring number of oil products decreased owing to the hydrogenation and ring-open of naphthenic hydrocarbon during the catalytic pyrolysis process. The highest HHV and the cetane index could be obtained when the oil product from the one-stage pyrolysis process of the oil field sludge with the oil field sludge ash was mixed with diesel by the mixing ratio of $1: 10$. The results of this study are of practical interest and will help to lead the researchers to more thinking about the oil recovery from oil sludge.
\end{abstract}

Keywords: Oil sludge; Oil sludge ash; Pyrolysis; Structural parameter

\section{Introduction}

Oil sludge, an inevitable by-product, is generated wherever exploitation, transportation and refining processes of petroleum industry. It is a complex mixture of petroleum hydrocarbons and water with solid mineral admixture [1]. In China, the growth of oil demand resulted in annual generation of over 110,000 tons of oil field sludge and 800,000 tons of oil storage tank sludge (oil tank sludge) [2]. Both the oil field sludge and the oil tank sludge comprise abundant of toxic substances from the most carcinogenic polycyclic aromatic to heavy metal, and even to radioactive material. Most of them pose the potential risks for human health and the environment. However, at several sites in China, the amount of uncontrolled disposal of oil sludge to the natural environment had reached or even exceeded 20 times of the assimilative capacity of receiving ecosystem. The major sources of oil sludge in this study include the oil field sludge, which is also called hydrocarbon contaminated soil, and the oil storage tank sludge derived from the tank cleaning process.

Currently, the most common way to dispose the oil sludge is immobilization and landfill, which requires much space and causes a serious threat to soil and groundwater environment. Biodegradation is considered to be a new and emerging method to decompose the organic compounds in the oil sludge into the lower molecular weight organic compounds. However, due to its unsatisfactory performance on the decompose process of asphaltene composition; this technique remains to be developed.

On the other hand, oil sludge is also a potential recycling resource for its high heating value. So the conversion of the stored energy of oil sludge to various fuel sources for power plants or engines has been recognized as an attractive approach. Some chemical recycling methods such as solvent extraction or adding the demulsifier have been tested by many researchers [3-5], and they are indeed feasible in improving the rate of oil recovery. Nevertheless, both of these ways need vast amount of extra organic solution or additive.

Thermal disposal methods: incineration and pyrolysis offer some benefits over these methods as is mentioned above in the aspect of energy recovery and waste reduction [6]. Since the existence of problems of the secondary pollution $[7,8]$ and the high viscosity of fuels [9], the application of incinerating oil sludge directly is limited. With its characteristics to crack high molecular weight organic compounds into lower ones, and to separate the stable emulsion of oil sludge into oil, water, and residue fraction efficiently, pyrolysis treatment were used widely in the field of oily waste disposal. A series of studies on the pyrolysis of oil sludge using TGA [10-15], rotary kiln [1], and fluidized bed [9] have been carried out. In these previous studies, the behavior of thermal conversion and the reaction models of the pyrolysis kinetics of oil sludge were proposed to explain the reaction mechanism. The oil products were reported to be close to diesel oil, however, they also contain certain amount of heavy components, like asphaltene, which affect the qualities of oil products severely $[15,16]$.

*Corresponding author: Shuo Cheng, Department of Environmental Science and Technology, Tokyo Institute of Technology, G5-8, 4259 Nagatsuta, Midori-ku, Yokohama 226-8502, Japan, Tel: +81 804338 2152; Fax: +81 45924 5518; E-mail: cheng.s.ab@m.titech.ac.jp

Received March 24, 2015; Accepted April 07, 2015; Published April 13, 2015

Citation:Cheng S, Li A, Yoshikawa K. (2015) PHigh Quality Oil Recovery from Oil Sludge Employing a Pyrolysis Process with Oil Sludge Ash Catalyst J Waste Resources 4: 176. doi: 10.4172/2252-5211.1000176

Copyright: () 2015 Cheng S, et al. This is an open-access article distributed unde the terms of the Creative Commons Attribution License, which permits unrestricted use, distribution, and reproduction in any medium, provided the original author and source are credited. 
To deal with this problem, the catalytic cracking, which means adding a useful catalyst or additive in the cracking process, has some advantages over the non-catalytic cracking. This catalyst adding method has a great potential to shorten the reaction time, lower the reaction temperature and narrow the product distribution [12]. In the previous study, the catalytic cracking of oil sludge in the presence of aluminum compounds $\left(\mathrm{Al}, \mathrm{Al}_{2} \mathrm{O}_{3}\right.$ and $\left.\mathrm{AlCl}_{3}\right)$; and iron compounds $\left(\mathrm{Fe}, \mathrm{Fe}_{2} \mathrm{O}_{3}, \mathrm{FeSO}_{4} \cdot 7 \mathrm{H}_{2} \mathrm{O}, \mathrm{FeCl}_{3}\right.$ and $\left.\mathrm{Fe}_{2}(\mathrm{SO} 4)_{3} \cdot \mathrm{nH}_{2} \mathrm{O}\right)$ [12] have been reported in detail. Based on the above studies, the addition of $\mathrm{Fe}_{2} \mathrm{O}_{3}$ and $\mathrm{Fe}_{2}\left(\mathrm{SO}_{4}\right)_{3} \cdot \mathrm{H}_{2} \mathrm{O}$ can improve the qualities of pyrolysis oil products. The effect of sodium compounds $\left(\mathrm{NaOH}, \mathrm{NaCl}\right.$ and $\left.\mathrm{Na}_{2} \mathrm{CO}_{3}\right)$; and potassium compounds $\left(\mathrm{KCl}, \mathrm{KOH}\right.$ and $\mathrm{K}_{2} \mathrm{CO}_{3}$ ) were tested by JeLuengShie and Ching-Yuan Chang [13]. They pointed out that $\mathrm{KCl}$ and $\mathrm{Na}_{2} \mathrm{CO}_{3}$ showed better performance in the pyrolysis process of oil tank sludge. Recently, these authors tested the catalytic solid wastes (DAY-zeolite and PVA), fly ash, and oil tank sludge ash as additive, and proved the effectiveness of fly ash and oil tank sludge ash in the improvement of oil quality [15]. However, most of the studies about catalytic cracking of oil sludge were carried out by TGA. Although, TGA can be seen as a simulation of fixed bed reactor, still there is a big difference between them.

In the present study, a series of pyrolysis experiment was conducted using a bench-scale fixed bed reactor, which is mainly consisted of a pyrolyzer and a reformer reactor. The experiment includes two basic pyrolytic methods namely: one-stage catalytic pyrolysis and two-stage catalytic pyrolysis. In the one-stage catalytic pyrolysis, the oil sludge was placed in the pyrolyzer reactor with a catalyst or an additive. In this case, however, the recovery of catalyst could be difficult. Therefore, the two-stage catalytic pyrolysis process is commonly used to treat the waste plastic. By this method, a high recovery rate of a catalyst can be guaranteed due to keeping the catalyst separate from the feedstock. One of the objectives of this study is to compare the pyrolysis effect of these two pyrolysis methods on the product yield and the quality of the pyrolysis oil obtained from two kinds of oil sludge.

Although most of the catalyst can be recovered from the reformer, they would be deactivated by poisoning, like sulfur, after several runs $[12,17]$. From the commercial point of view, the catalyst or additive should be cheap and easily available material. Therefore, anther objective of this study is to identify the catalytic effect of oil sludge ash, which is considered to be a waste of the disposal process of oil sludge, and comparing it with some common catalysts such as ZSM-5 zeolite, activated $\mathrm{Al}_{2} \mathrm{O}_{3}$, and a natural zeolite obtained from Indonesia. More detailed information of the catalysts used in this study will be explained in the experimental section.

The effects of the pyrolysis method and the catalysts on the yields and properties of oil products obtained from pyrolysis of oil sludge were investigated in this study. Characterization of the oil products was preliminary judged by comparing their distillation results with the diesel standard. Then, the chemical characterization of a part of the pyrolytic oils was conducted by FT-IR and NMR. In the last step of this experiment, the oil products obtained from pyrolysis of oil sludge using oil field sludge ash and oil tank sludge ash as catalysts were mixed with diesel oil by the volume ratio of one-to-five and one-to-ten. The fuel characteristic of the oil mixtures was analyzed by GC-MS, and identified from the view point of the viscosity, the density, the cetane index, the carbon number distribution and the heating value.

\section{Materials and Methods \\ Oil sludge}

Both the oil field sludge and the oil storage tank sludge used in this study were sampled from Shengli oil field, China. The oil field sludge is finely gritty texture which is wet by crude oil. As to the oil tank sludge, it generally is dark and viscous slurry, and there is almost no particulate material can be found in it. Table 1 shows the results of the proximate analysis, the ultimate analysis, the higher heating value (HHV), the oil content and a part of metal element analysis results of the oil sludge.

The moisture, volatile, and ash were measured according to the standard test method ASTM E871, D1102, and E872. The fixed carbon was calculated by the difference to $100 \%$. There is a considerable difference between the proximate analysis results of the oil field sludge and the oil storage tank sludge. It may be due to the different resource of these two sludge samples. The ultimate analysis was performed using a CHNS/O analyzer. The oxygen was estimated by subtracting the sum of $\mathrm{C}, \mathrm{H}, \mathrm{N}, \mathrm{S}$, and ash constituent from 100. A bomb calorimeter was employed to measure the low heating value of the samples. The oil content and the high heating value of the oil storage tank sludge are more than double of those of the oil field sludge. Shengli crude oil is a relatively high-Ni, high-nitrogen, and intermediate base crude oil. The oil sludge from Shengli oil field and storage tanks inherited these genetic characteristics, which will pose a threat to catalysts. Sludge drying can remove a part of moisture from the samples, but it also cause light hydrocarbon volatilization and leads to a loss of oil recovery. Moreover, the dried sludge became stickier, more dense, and hard to be treated. Therefore, in all experiments of this study, the oil sludge was used as it was received.

\section{Catalysts}

The following five catalysts were selected for use in the catalytic cracking:

\begin{tabular}{|c|c|c|}
\hline & Oil field sludge & Oil tank sludge \\
\hline \multicolumn{3}{|l|}{ Proximate analysis } \\
\hline \multicolumn{3}{|l|}{ (Wt\% wet basis) } \\
\hline Moisture & 7.63 & 20.61 \\
\hline Volatile & 14.57 & 41.59 \\
\hline Fixed carbon & 8.47 & 4.62 \\
\hline Ash & 76.96 & 33.18 \\
\hline \multicolumn{3}{|l|}{ Ultimate analysis } \\
\hline \multicolumn{3}{|l|}{ (Wt\% dat) } \\
\hline$C$ & 16.89 & 58.97 \\
\hline $\mathrm{H}$ & 2.32 & 9.14 \\
\hline $\mathrm{N}$ & 0.16 & 1.21 \\
\hline$S$ & 0.53 & 1.91 \\
\hline $\mathrm{O}(\mathrm{a})$ & 2.6 & 4.67 \\
\hline $\mathrm{H} / \mathrm{C}(\mathrm{mol} / \mathrm{mol})$ & 1.65 & 1.86 \\
\hline $\mathrm{S} / \mathrm{C}(\mathrm{mol} / \mathrm{mol})$ & 0.0118 & 0.0121 \\
\hline $\mathrm{N} / \mathrm{C}(\mathrm{mol} / \mathrm{mol})$ & 0.0082 & 0.0175 \\
\hline HHV (MJ/kg) & 10.45 & 21.51 \\
\hline Oil content (wt\%) & 21.65 & 43.2 \\
\hline \multicolumn{3}{|l|}{$\begin{array}{l}\text { Metal element analysis } \\
(\text { ppmw) }\end{array}$} \\
\hline $\mathrm{Fe}$ & 14865.98 & 955.92 \\
\hline $\mathrm{Cu}$ & 22.55 & 2.36 \\
\hline $\mathrm{Na}$ & 164.35 & 620.31 \\
\hline $\mathrm{Ni}$ & 23.44 & 5.3 \\
\hline V & 20.28 & 18.54 \\
\hline
\end{tabular}

Table 1: Selected properties and composition of the tested oil sludge obtained from Shengli oil field. 
1. Oil field sludge ash: a mixture of metallic oxide, amorphous, surface area: $4.74 \mathrm{~m}^{2} / \mathrm{g}$, pore volume: $0.024 \mathrm{~cm}^{3} / \mathrm{g}$, mean pore size: $20.57 \mathrm{~nm}$, mesopore structure. It was prepared by burning the pyrolysis residue of the oil field sludge in a muffle furnace at $600^{\circ} \mathrm{C}$ for 3 hours.

2. Oil storage tank sludge ash: a mixture of metallic oxide, amorphous, surface area: $135.34 \mathrm{~m}^{2} / \mathrm{g}$, pore volume: 0.415 $\mathrm{cm}^{3} / \mathrm{g}$, mean pore size: $12.28 \mathrm{~nm}$, mesopore structure. The preparation process is the same as the oil field sludge ash.

3. Natural zeolite (obtained from Indonesia): Crystalline aluminosilicate (with impurities), mordenite, $\mathrm{SiO}_{2} / \mathrm{Al}_{2} \mathrm{O}_{3}$ (mole ratio): 8.12 , surface area: $50.54 \mathrm{~m}^{2} / \mathrm{g}$, pore volume: $0.134 \mathrm{~cm}^{3} / \mathrm{g}$, mean pore size: $10.61 \mathrm{~nm}$, mesopore structure.

4. Activated aluminium oxide: Aluminium oxide, amorphous, surface area: $319.93 \mathrm{~m}^{2} / \mathrm{g}$, pore volume: $0.371 \mathrm{~cm}^{3} / \mathrm{g}$, mean pore size: $4.64 \mathrm{~nm}$, mesopore and micropore structure.

5. ZSM-5: Crystalline aluminosilicate, mordenit, $\mathrm{SiO}_{2} / \mathrm{Al}_{2} \mathrm{O}_{3}$ (mole ratio): 80 , surface area: $425 \mathrm{~m}^{2} / \mathrm{g}$, pore volume: 0.365 $\mathrm{cm}^{3} / \mathrm{g}$, mean pore size: $4.51 \mathrm{~nm}$, mesopore and micro pore structure.

The chemical components of the oil sludge ashes and the natural zeolite are listed in Table 2. From this table, we can see that the main components of the oil field sludge ash and the oil storage tank ash are $\mathrm{SiO}_{2}, \mathrm{Al}_{2} \mathrm{O}_{3}, \mathrm{CaO}, \mathrm{Fe}_{2} \mathrm{O}_{3}$, and $\mathrm{SO}_{3}$. Also from this table, we can see that the main components of natural zeolite are $\mathrm{SiO}_{2}, \mathrm{Al}_{2} \mathrm{O}_{3}, \mathrm{CaO}, \mathrm{Fe}_{2} \mathrm{O}_{3}$, and $\mathrm{K}_{2} \mathrm{O}$. The natural zeolite has been proved that it is effective and applicable to recovery the diesel range fuel from waste plastic. It works on breaking the macromolecules into smaller ones. As Table 2 presents, the oil sludge ash has the similar chemical components with natural zeolite. Considering the result of Je-LuengShie [15], we speculate that the adding of oil sludge ash has the ability to affect the yield and quality of the oil product to some extent. However, the ratios of components of the oil sludge ash are quite different from those of natural zeolite.

\section{Experimental apparatus}

The pyrolysis and catalytic reforming experiments were carried out using a self-fabricated stainless steel two stage reactor, which is shown in Figure 1. This system consists of the pyrolysis reactor and the catalytic reforming reactor. The inner diameter and the height of the pyrolysis reactor are $43 \mathrm{~mm}$ and $284 \mathrm{~mm}$, respectively. As to the reformer, its inner diameter is $38 \mathrm{~mm}$, and the height is $210 \mathrm{~mm}$. Both of the reactors were covered with the electric heater, and the reaction temperatures in both the pyrolysis reactor and the reforming reactor

Table 2: Chemical components of oil field sludge ash, oil tank sludge ash, and natural zeolite.

\begin{tabular}{|c|c|c|c|}
\hline $\mathrm{Wt} \%$ & Oil field sludge ash & Oil tank sludge ash & Natural zeolite \\
\hline $\mathrm{SiO}_{2}$ & 54.4 & 25.6 & 68.76 \\
\hline $\mathrm{Al}_{2} \mathrm{O}_{3}$ & 11.5 & 40.3 & 14.4 \\
\hline $\mathrm{CaO}$ & 9.69 & 6.79 & 10.47 \\
\hline $\mathrm{Fe}_{2} \mathrm{O}_{3}$ & 8.29 & 7.7 & 4.24 \\
\hline $\mathrm{K}_{2} \mathrm{O}$ & 3.6 & 1.09 & 1.08 \\
\hline $\mathrm{MgO}$ & 1.76 & 1.37 & 0.45 \\
\hline $\mathrm{Na}_{2} \mathrm{O}$ & 1.37 & 2.89 & 0.31 \\
\hline $\mathrm{TiO}_{2}$ & 1.36 & 1.6 & - \\
\hline $\mathrm{SrO}^{\mathrm{N} O}$ & 0.13 & 0.17 & - \\
\hline $\mathrm{SO}_{3}$ & 7.11 & 11.1 & - \\
\hline Ignition loss & 0.519 & 0.475 & 0.29 \\
\hline
\end{tabular}

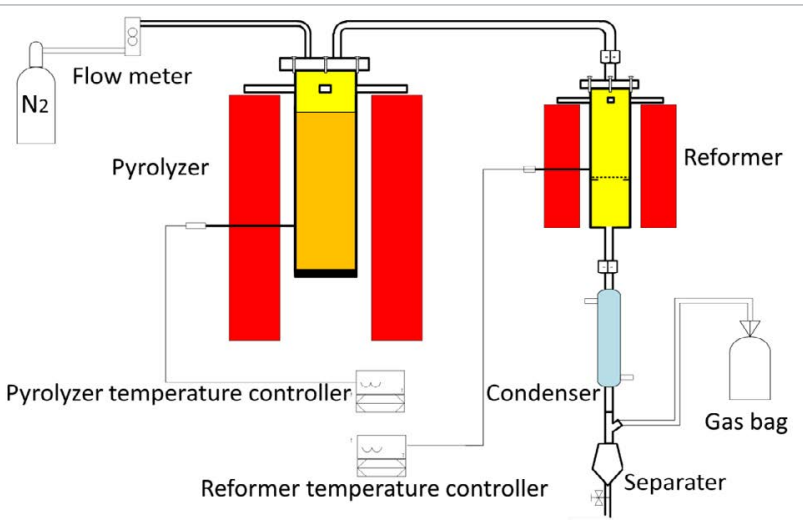

Figure 1: Diagram of the bench-scale pyrolysis and catalytic reforming reactors.

were controlled by a closed loop feedback system, including K-type thermocouples, a controller, and a heater. A double-tube condenser was installed at the outlet side of the reformer, and another side of it was connected to the gas/liquid separator.

\section{Pyrolysis experiment}

Pyrolysis experiment was conducted using the stainless steel pyrolyzer coupled with the reforming reactor made of the same material. In the one stage reaction case, $60 \mathrm{~g}$ of oil sludge was mixed with $20 \mathrm{~g}$ of catalyst, and then the mixture was placed in the pyrolyzer. In the case of the two stage reaction, $60 \mathrm{~g}$ of oil sludge and $20 \mathrm{~g}$ of catalyst were put into the pyrolyzer and the reformer, respectively. In the reformer side, on the top surface of the catalyst, $40 \mathrm{~g}$ of quartz sand were packed to ensure that the catalyst was flatten and separated from the solid particles carried by the pyrolysis gas. To compare with the two stage reaction case, the reformer side of the one stage reaction case was also filled with $40 \mathrm{~g}$ of quartz sand. $\mathrm{N}_{2}$ carrier gas with the flow rate of $50 \mathrm{ml} / \mathrm{min}$ was passed through the pyrolysis and reforming reactors before the experiments for lhour, to remove the air in the reactors. After the air in the reactors was replaced with $\mathrm{N}_{2}$, the reformer was heated to $500^{\circ} \mathrm{C}$ first to dry and activate the catalyst and the quartz sand. Then the pyrolyzer was heated at the rate of $20^{\circ} \mathrm{C} / \mathrm{min}$ until the temperature reached to $500^{\circ} \mathrm{C}$, and held at this temperature for 1 hour. When the temperature rose to around $390^{\circ} \mathrm{C}$, due to the endothermic reaction of the oil sludge, the heating rate dropped obviously. Then the temperature hovered at around $395^{\circ} \mathrm{C}$ for 2 minutes. After this stagnation, the temperature continued to rise. The quantity of the pyrolysis gas began to increase when the temperature reached to $450^{\circ} \mathrm{C}$. The reformed gas was introduced to the condenser in which the reaction mixture was cooled to the room temperature. The condensable (liquid product) and the non-condensable (gas product) parts were separated in the gas-liquid separator and collected in the liquid collector and the gas collector respectively. The products can be classified into: gas, liquid (oil and water), and solid residue. The liquid and solid products were weighted, and the yields of gas were calculated by the difference.

\section{Analysis}

The instruments used for the analysis of the oil product and the mixed fuel oil are given below.

Fourier transform infrared spectrometer (FT-IR): FT-IR was considered as a common analysis technique by the researchers of heavy oil and asphaltene field $[1,18]$. In this study, FT-IR analysis of the pyrolytic oil was conducted by JEOL JIR-SPX200 FT-IR spectrometer. 
The oil samples were prepared as a cast film between two $\mathrm{KBr}$ windows, and the range of wave number was set from 400 to 4000 .

Nuclear magnetic resonance (NMR) ${ }^{1} \mathrm{H},{ }^{13} \mathrm{C}$ : The results of NMR analysis are often used to speculate the molecular structure of organism, and calculate the average structural parameters of crude oil and heavy oil by bringing the chemical shift results into the equation list of Brown-Ladner method [19] or the other method. Our NMR results of oil products were carried out using a BrukerbiospinAvance III NMR spectrometer. The relative peak areas were captured in accordance with the range of: $\mathrm{H \alpha}(2.0 \sim 4.0 \mathrm{ppm}) ; \mathrm{H} \beta(1.0 \sim 2.0 \mathrm{ppm}) ; \mathrm{H} \gamma(0.5 \sim 1.0 \mathrm{ppm})$; HA (9.0 6.0 ppm); CA (190 100 ppm); CP (70 0 ppm). The average structural parameters of oil products were calculated according to the method described $[19,20]$.

Thermogravimetry analysis (TG): A thermo-gravimetry instrument can measure weight changes of a solid and liquid material under the temperature programmed condition in a controlled atmosphere. It is believed to be an feasible way to analyze the distillation characteristics (below $400^{\circ} \mathrm{C}$ ) of fuel oil, heavy oil, and tar oil by using TGA system $[21,22]$. The SHIMADZU D 50 simultaneous TGA/DTA analyzer was used to define the distillation characteristics of pyrolytic oil products. $20 \mathrm{mg}$ of liquid samples was placed in a platinum micro crucible. For controlling liquid flooding and increasing detection precision, a micro cover with a small gas vent was placed on the crucible before measurement. Then the whole crucible assembly was heated in $\mathrm{N}_{2}$ at the flow rate of $50 \mathrm{ml} / \mathrm{min}$. Data collection was carried out from $30^{\circ} \mathrm{C}$ to $450^{\circ} \mathrm{C}$. During the whole measurement process, the heating rate was kept at $5^{\circ} \mathrm{C} / \mathrm{min}$. The results were compared with a diesel standard, which was got from ENEOS gasoline station, Japan.

Gas chromatography to mass spectroscopy (GC-MS): The GCMS analysis of the mixed fuel (diesel and oil product) was conducted by employing an Agilent 19091S-433 with HP-5MS Phenyl Methyl Siloxane $(30.0 \mathrm{~m} \times 250 \mu \mathrm{m} \times 0.25 \mu \mathrm{m})$ column. The carrier gas was He. The temperature was held at $50^{\circ} \mathrm{C}$ for 3 minutes, then was increased to $200^{\circ} \mathrm{C}$ at the heating rate of $3^{\circ} \mathrm{C} / \mathrm{min}$, and then was held for 40 minutes. The chemical compounds found in the injected samples were identified by comparing their spectra with the data base of the GC-MS system.

\section{Results and Discussion}

There are five parts in this section. The first part focuses on the effect of catalysts on the yield of pyrolysis products. Part 2 provides the results of distillation characteristics of all the oil products. The ratio of remaining carbon and the mole $\mathrm{H} / \mathrm{C}, \mathrm{O} / \mathrm{C}, \mathrm{S} / \mathrm{C}$, and $\mathrm{N} / \mathrm{C}$ are also discussed in this part. Part 3 and Part 4 go further into the chemical characteristics of the selected typical oil samples, such as the oil product from the one stage pyrolysis of oilfield sludge over the oilfield sludge ash, and the oil product of oil tank sludge, which was produced in one stage pyrolysis process with oil tank sludge ash. The FT-IR analysis and NMR analysis are used to indicate some main functional groups and the chemical structure of oil products in these parts. The last part discusses the fuel characteristics of the mixed fuel of oil products with diesel. Some evaluation indexes, like the density, the viscosity, the carbon distribution, the heating value, and the cetane index are provided in this part. The results presented in this section are the mean values of at least three experiment runs and analysis under the same conditions.

\section{Effect of experiment conditions on the yield of pyrolysis products}

The liquid product (oil and water) distribution for the oil field

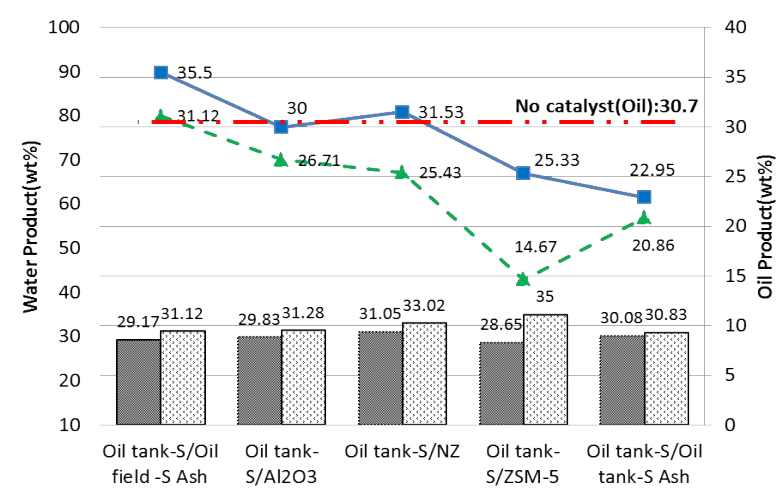

Figure 2: Effect of the catalysts and pyrolysis methods on the oil and water yields of the oil tank sludge.

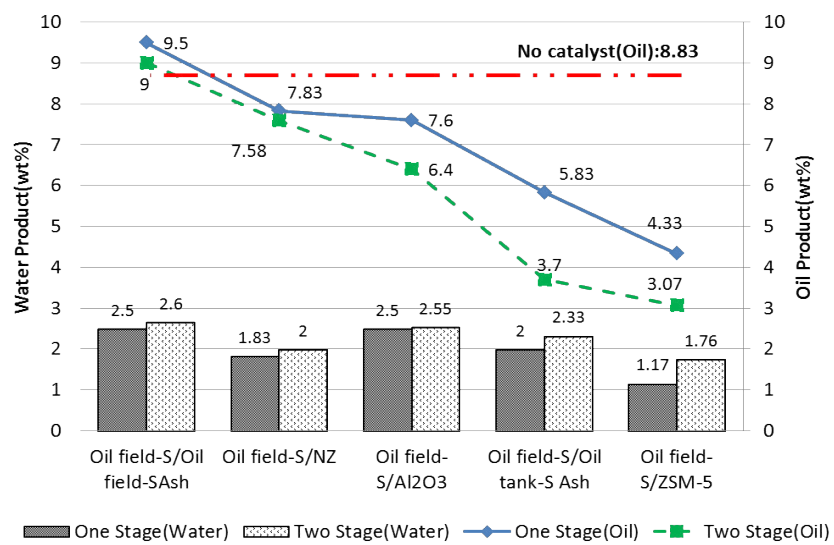

Figure 3: Effect of the catalysts and pyrolysis methods on the oil and water yields of the oil field sludge.

sludge and oil tank sludge are presented in Figures 2 and 3, respectively. The oil product under different experiment conditions are shown by the line graphs. Their Y-axis is on the right side. The bars whose Y-axis is on the left side show the water product yield. On the whole, the oil products of the one stage pyrolysis are higher than the two stage case, whether the feedstock is the oil field sludge or the oil tank sludge. This might be caused by the fully functioning of catalysts in the reformer, which would lead to the increasing of gas product and the decreasing of oil product. However, the opposite occurs in water products.

As seen from Figure 2, the oil product of the oil tank sludge, about $35.5 \mathrm{wt} \%$, in the one stage pyrolysis, with the catalyst of the oil field sludge ash is higher than the oil products with other catalysts(31.53-22.95 wt\%), and higher than that without catalyst(30.7 $\mathrm{wt} \%)$. In Figure 3, The highest oil product yield (9.5 wt\%) of the oil field sludge is also obtained at one stage pyrolysis with the oil field sludge ash. According to the main components of the oil sludge ash (Table 2), both the oil field sludge ash and the oil tank sludge ash contained lots of Fe oxide and S oxide. Previous studies [12,23] proved that the presence of $\mathrm{Fe}$ element and $\mathrm{S}$ element in the catalyst can improve the conversion of oil sludge by inhibiting the agglomeration of metal oxides and increasing the surface area of catalysts. This advantage became more meaningful in the one stage pyrolysis. The oil field sludge ash improved the physical contact between the oil sludge and the catalyst, and resulted in improved oil recovery. That might explain 
why the one stage pyrolysis with the oil field sludge ash can produce more oil product. We noted then that compared with other catalysts, the oil product yield over the oil tank sludge ash stayed on a lower level, due to their higher amounts of gas products. This tendency is generally similar to the pyrolysis experiments with the ZSM-5 catalyst. Here we can speculate that the oil tank sludge ash has a higher catalytic activity or dispersive capacity than the oil field sludge ash, even though there are only a few differences in their main components.

As to the gas and residue product yields which can be seen from Figures 4 and 5, the gas product yields from the one stage pyrolysis are lower than that from the two stage pyrolysis. This trend once again proves that the catalysts functioned fully in the two stage case, and enhanced the cracking of large molecule products into small molecules such as some non-condensable gas molecules. The residue product yields of the catalystic pyrolysis of the oil field sludge are generally above $80 \mathrm{wt} \%$, owing to the high ash content of the oil field sludge.

\section{Distillation characteristics of oil products}

The distillation characteristics of oil products having the boiling range between $30^{\circ} \mathrm{C}$ to $400^{\circ} \mathrm{C}$ were determined at the atmospheric pressure using a thermo-gravimetry instrument. Tests revealed the boiling range of all the oil samples were between $90^{\circ} \mathrm{C}$ and $370^{\circ} \mathrm{C}$. The distillation characteristic curves are given in Figures 6 and 7. The ratio

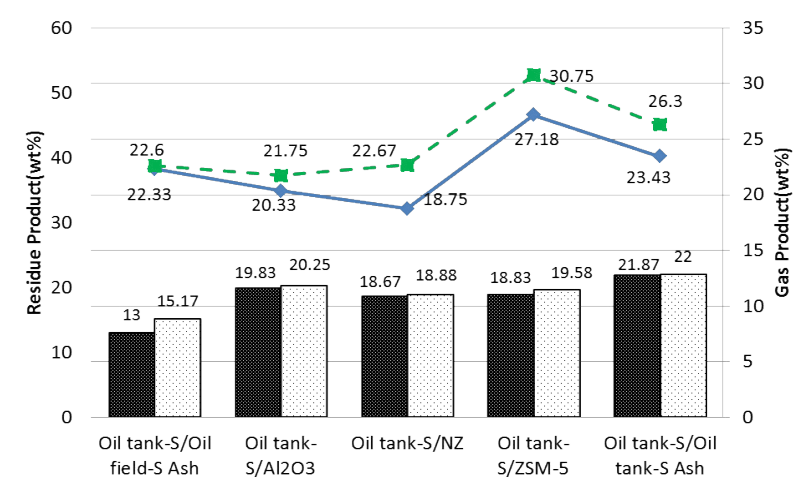

Figure 4: Effect of the catalysts and pyrolysis methods on the gas and residue yields of the oil tank sludge.

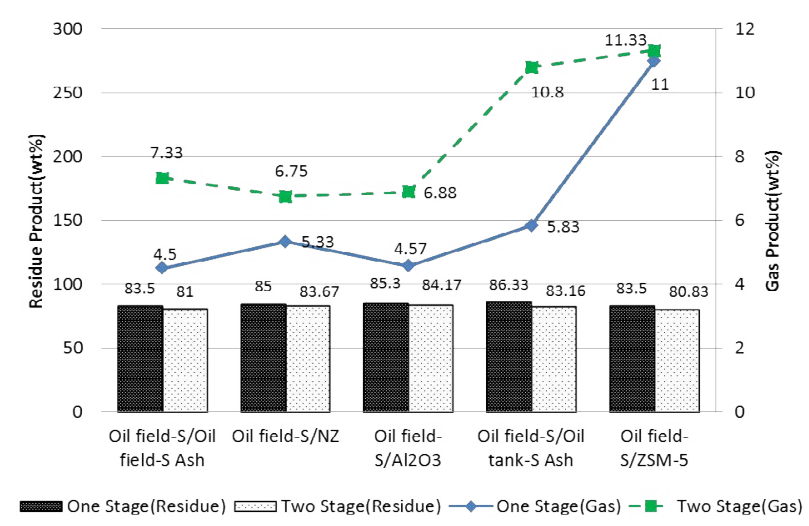

Figure 5: Effect of the catalysts and pyrolysis methods on the gas and residue yields of the oil field sludge.

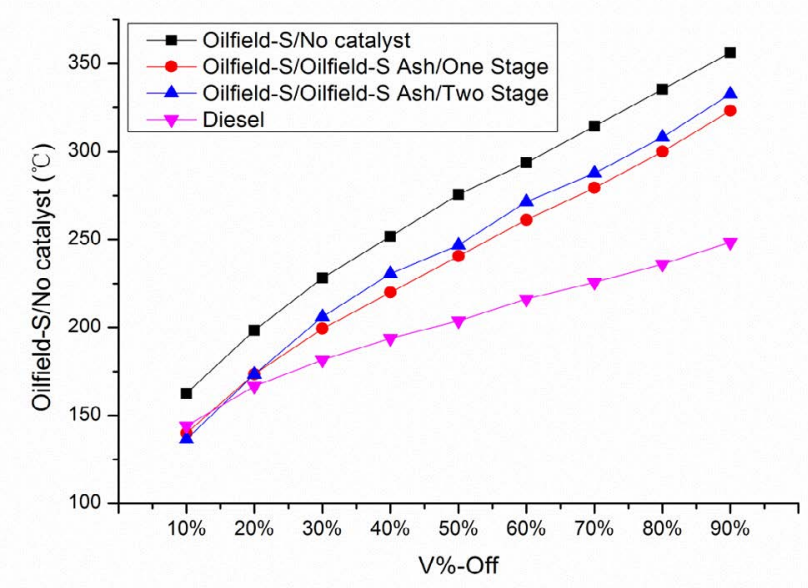

Figure 6a: Boiling point range distribution curves of the oil product from the catalytic pyrolysis of the oil field sludge with the oil field sludge ash.

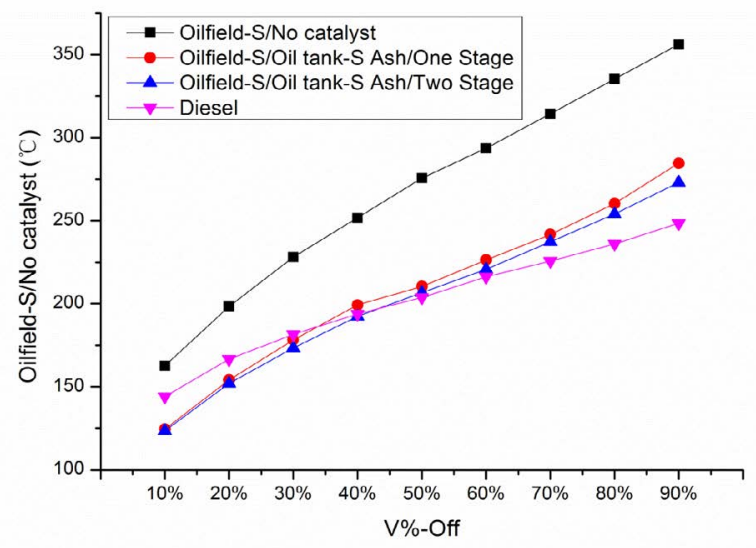

Figure 6b: Boiling point range distribution curves of the oil product from the catalytic pyrolysis of the oil field sludge with the oil tank sludge ash

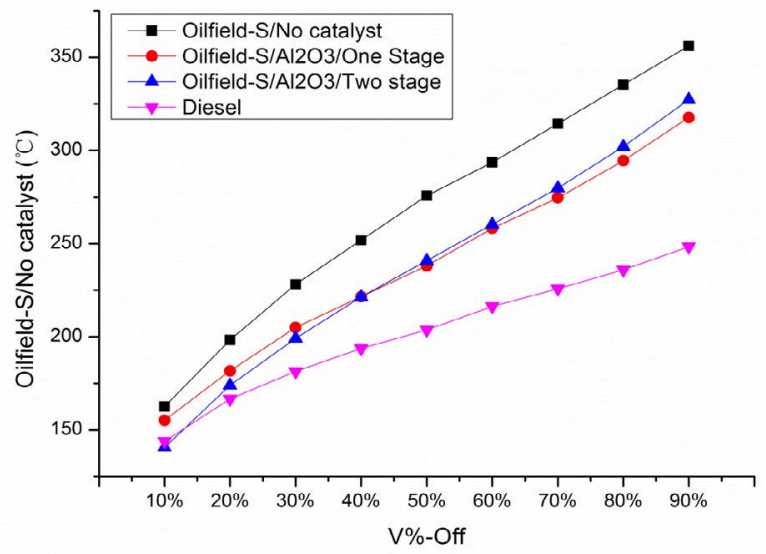

Figure 6c: Boiling point range distribution curves of the oil product from the catalytic pyrolysis of the oil field sludge with the activated aluminium oxide.

of remaining carbon at $450^{\circ} \mathrm{C}$, which show the yield of coke in the oil product, are listed in Tables 3 and 4 . The ratio of remaining carbon 


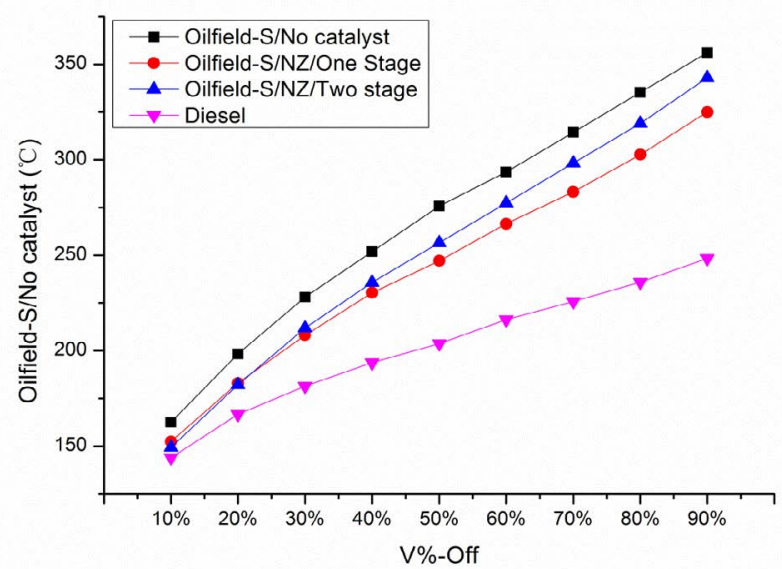

Figure 6d: Boiling point range distribution curves of the oil product from the catalytic pyrolysis of the oil field sludge with natural zeolite.

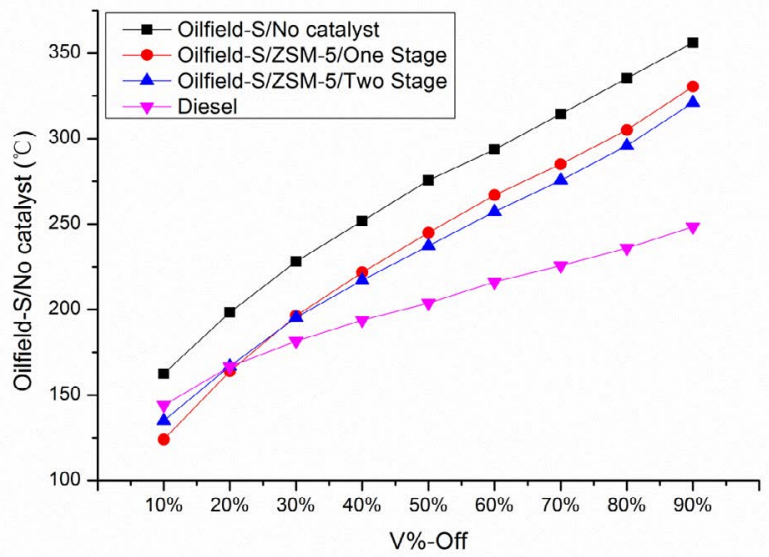

Figure 6e: Boiling point range distribution curves of the oil product from the catalytic pyrolysis of the oil field sludge with ZSM-5.

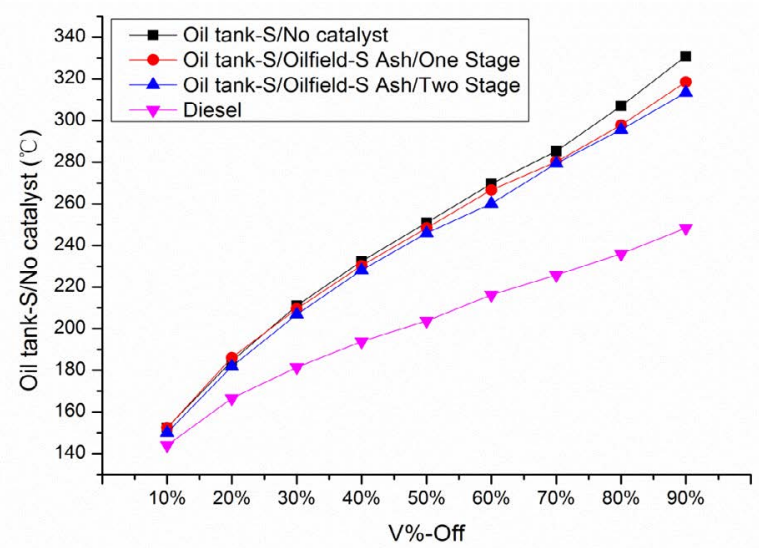

Figure 7a: Boiling point range distribution curves of the oil product from the catalytic pyrolysis of the oil tank sludge with the oil field sludge ash.

can reflect the amount of carbon deposition when the oil products are used in an engine. Both the distillation characteristics and the ratio of remaining carbon are the important evaluation parameters of oil quality.

From Figures 6 and 7, we can see that the distillation characteristic

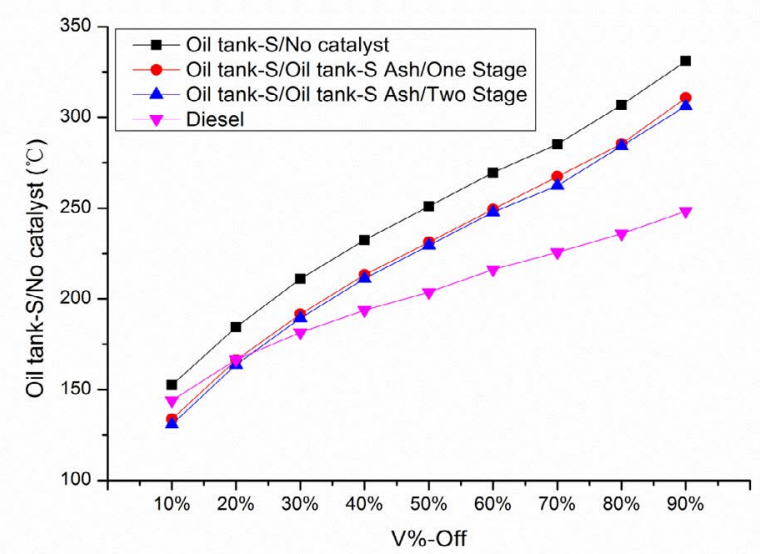

Figure 7b: Boiling point range distribution curves of the oil product from the catalytic pyrolysis of the oil tank sludge with the oil tank sludge ash.

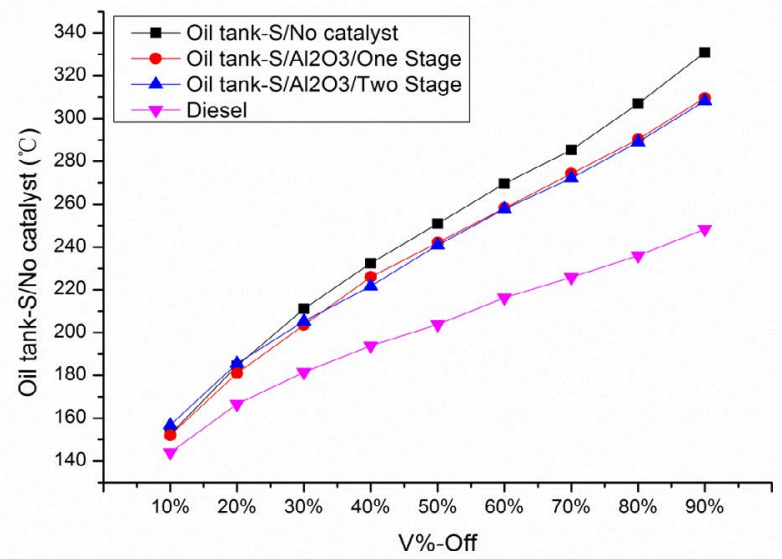

Figure 7c: Boiling point range distribution curves of the oil product from the catalytic pyrolysis of the oil tank sludge with activated aluminium oxide.

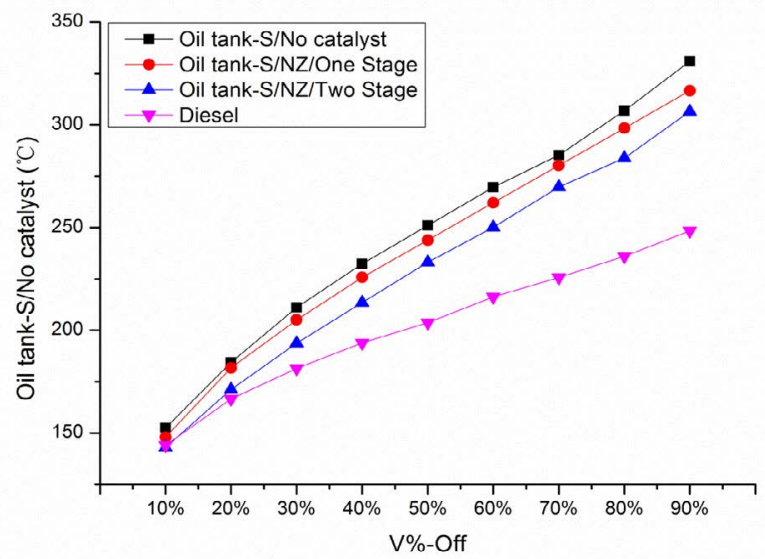

Figure 7d: Boiling point range distribution curves of the oil product from the catalytic pyrolysis of the oil tank sludge with natural zeolite. 


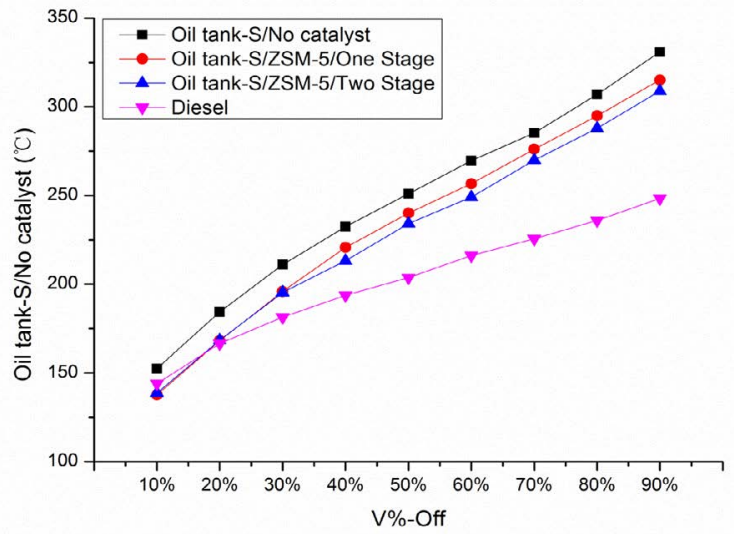

Figure 7e: Boiling point range distribution curves of the oil product from the catalytic pyrolysis of the oil tank sludge with ZSM-5.

\begin{tabular}{|l|l|l|l|}
\hline & $\begin{array}{l}\text { Oilfield-S } \\
\text { Oilfield-S Ash } \\
\text { One stage }\end{array}$ & $\begin{array}{l}\text { Oilfield-S } \\
\text { Oil field-S Ash } \\
\text { Two stage }\end{array}$ & $\begin{array}{l}\text { Oilfield-S } \\
\text { No catalyst }\end{array}$ \\
\hline $\begin{array}{l}\text { Ratio of } \\
\text { remaining } \\
\text { carbon }\end{array}$ & $6.25 \%$ & $6.75 \%$ & $8.25 \%$ \\
\hline
\end{tabular}

Table 3(a): Ratio of remaining carbon in the oil product from the catalytic pyrolysis of the oil field sludge with the oil tank sludge ash.

\begin{tabular}{|l|l|l|l|}
\hline & $\begin{array}{l}\text { Oilfield-S } \\
\text { Oil tank-S Ash } \\
\text { One stage }\end{array}$ & $\begin{array}{l}\text { Oilfield-S } \\
\text { Oil tank-S Ash } \\
\text { Two stage }\end{array}$ & $\begin{array}{l}\text { Oilfield-S } \\
\text { No catalyst }\end{array}$ \\
\hline $\begin{array}{l}\text { Ratio of } \\
\text { remaining } \\
\text { carbon }\end{array}$ & $5 \%$ & $6.25 \%$ & $8.25 \%$ \\
\hline
\end{tabular}

Table 3(b): Ratio of remaining carbon in the oil product from the catalytic pyrolysis of the oil field sludge with the oil tank sludge ash.

\begin{tabular}{|l|l|l|l|}
\hline & $\begin{array}{l}\text { Oilfield-S } \mathrm{Al}_{2} \mathrm{O}_{3} \\
\text { One stage }\end{array}$ & $\begin{array}{l}\text { Oilfield-S } \mathrm{Al}_{2} \mathrm{O}_{3} \\
\text { Two stage }\end{array}$ & $\begin{array}{l}\text { Oilfield-S } \\
\text { No catalyst }\end{array}$ \\
\hline $\begin{array}{l}\text { Ratio of remaining } \\
\text { carbon }\end{array}$ & $3.75 \%$ & $9.25 \%$ & $8.25 \%$ \\
\hline
\end{tabular}

Table 3(c): Ratio of remaining carbon in the oil product from the catalytic pyrolysis of the oil field sludge with activated aluminium oxide.

\begin{tabular}{|c|c|c|c|}
\hline & $\begin{array}{c}\text { Oilfield-S } \\
\text { NZ } \\
\text { One stage }\end{array}$ & $\begin{array}{c}\text { Oilfield-S } \\
\text { NZ } \\
\text { Two stage }\end{array}$ & $\begin{array}{c}\text { Oilfield-S } \\
\text { No catalyst }\end{array}$ \\
\hline $\begin{array}{c}\text { Ratio of remaining } \\
\text { carbon }\end{array}$ & $5.25 \%$ & $10 \%$ & $8.25 \%$ \\
\hline
\end{tabular}

Table 3(d): Ratio of remaining carbon in the oil product from the catalytic pyrolysis of the oil field sludge with natural zeolite.

\begin{tabular}{|c|c|c|c|}
\hline & $\begin{array}{c}\text { Oilfield-S } \\
\text { ZSM-5 } \\
\text { One stage }\end{array}$ & $\begin{array}{c}\text { Oilfield-S } \\
\text { ZSM-5 } \\
\text { Two stage }\end{array}$ & $\begin{array}{c}\text { Oilfield-S } \\
\text { No catalyst }\end{array}$ \\
\hline $\begin{array}{c}\text { Ratio of } \\
\text { remaining carbon }\end{array}$ & $4.75 \%$ & $7 \%$ & $8.25 \%$ \\
\hline
\end{tabular}

Table 3(e): Ratio of remaining carbon in the oil product from the catalytic pyrolysis of the oil field sludge with ZSM-5.

curves of oil products, whether from the pyrolysis of the oil field sludge or the oil tank sludge, are located between the curve for no catalyst oil product and the curve for diesel standard. It means that the boiling range of all the oil products produced by the catalytic pyrolysis are in between the boiling range of no catalyst oil product and diesel standard. The results indicate that in the catalytic pyrolysis process of the oil field sludge, all of the catalysts can improve the quality of oil products by decreasing their boiling point range. In Figure 6-b, we can see that the boiling range of the oil product with the use of the catalyst of the oil tank sludge ash (one stage case: $124.5 \sim 284.5^{\circ} \mathrm{C}$; two stage case: $123.4 \sim 273^{\circ} \mathrm{C}$ ) is the nearest to the boiling range of diesel standard $\left(144 \sim 248.4^{\circ} \mathrm{C}\right)$.

Although there is no obvious differences between the one stage pyrolysis and the two stage pyrolysis in the boiling range, the ratio of remaining carbon in the oil product from the one stage pyrolysis process, shown in Table 3, are generally lower than those from the two stage pyrolysis process, and also lower than the oil product from the no catalyst pyrolysis process. Therefore, the oil products from the one stage pyrolysis process of the oil field sludge contained lower coke amount than the oil product produced by the two stage pyrolysis of the same feedstock.

For the distillation characteristic of the oil products from the catalytic pyrolysis of the oil tank sludge, it was found that neither the type of the catalyst nor the pyrolysis method affected the boiling range of the oil product significantly, except for the oil product with the catalyst of the oil tank sludge ash and ZSM-5. On the other hand, the ratio of remaining carbon in the no catalyst oil product $(17.5 \mathrm{wt} \%)$ is

\begin{tabular}{|c|c|c|c|}
\hline & $\begin{array}{c}\text { Oil tank-S } \\
\text { Oilfield-S Ash } \\
\text { One stage }\end{array}$ & $\begin{array}{c}\text { Oil tank-S } \\
\text { Oilfield-S Ash } \\
\text { Two stage }\end{array}$ & $\begin{array}{c}\text { Oil tank-S } \\
\text { No catalyst }\end{array}$ \\
\hline $\begin{array}{c}\text { Ratio of } \\
\text { remaining carbon }\end{array}$ & $7.25 \%$ & $4.25 \%$ & $17.5 \%$ \\
\hline
\end{tabular}

Table 4(a): Ratio of remaining carbon in the oil product from the catalytic pyrolysis of the oil tank sludge with the oil field sludge ash.

\begin{tabular}{|c|c|c|c|}
\hline & $\begin{array}{c}\text { Oil tank-S } \\
\text { Oil tank-S Ash } \\
\text { One stage }\end{array}$ & $\begin{array}{c}\text { Oil tank-S } \\
\text { Oil tank-S Ash } \\
\text { Two stage }\end{array}$ & $\begin{array}{c}\text { Oil tank-S } \\
\text { No catalyst }\end{array}$ \\
\hline $\begin{array}{c}\text { Ratio of remaining } \\
\text { carbon }\end{array}$ & $7.5 \%$ & $3 \%$ & $17.5 \%$ \\
\hline
\end{tabular}

Table 4(b): Ratio of remaining carbon in the oil product from the catalytic pyrolysis of the oil tank sludge with the oil tank sludge ash.

\begin{tabular}{|c|c|c|c|}
\hline & $\begin{array}{c}\text { Oil tank-S } \\
\mathbf{A l}_{2} \mathbf{O}_{3} \\
\text { One stage }\end{array}$ & $\begin{array}{c}\text { Oil tank-S } \\
\mathbf{A l}_{2} \mathbf{O}_{3} \\
\text { Two stage }\end{array}$ & $\begin{array}{c}\text { Oil tank-S } \\
\text { No catalyst }\end{array}$ \\
\hline $\begin{array}{c}\text { Ratio of remaining } \\
\text { carbon }\end{array}$ & $3.75 \%$ & $2.75 \%$ & $17.5 \%$ \\
\hline
\end{tabular}

Table 4(c): Ratio of remaining carbon in the oil product from the catalytic pyrolysis of the oil tank sludge with activated aluminium oxide.

\begin{tabular}{|c|c|c|c|}
\hline & $\begin{array}{c}\text { Oil tank-S } \\
\text { NZ } \\
\text { One stage }\end{array}$ & $\begin{array}{c}\text { Oil tank-S } \\
\text { NZ } \\
\text { Two stage }\end{array}$ & $\begin{array}{c}\text { Oil tank-S } \\
\text { No catalyst }\end{array}$ \\
\hline $\begin{array}{c}\text { Ratio of remaining } \\
\text { carbon }\end{array}$ & $8.25 \%$ & $5.25 \%$ & $17.5 \%$ \\
\hline
\end{tabular}

Table 4(d): Ratio of remaining carbon in the oil product from the catalytic pyrolysis of the oil tank sludge with natural zeolite.

\begin{tabular}{|c|c|c|c|}
\hline & $\begin{array}{c}\text { Oil tank-S } \\
\text { ZSM-5 } \\
\text { One stage }\end{array}$ & $\begin{array}{c}\text { Oil tank-S } \\
\text { ZSM-5 } \\
\text { Two stage }\end{array}$ & $\begin{array}{c}\text { Oil tank-S } \\
\text { No catalyst }\end{array}$ \\
\hline $\begin{array}{c}\text { Ratio of remaining } \\
\text { carbon }\end{array}$ & $7.25 \%$ & $0.75 \%$ & $17.5 \%$ \\
\hline
\end{tabular}

Table 4(e): Ratio of remaining carbon in the oil product from the catalytic pyrolysis of the oil tank sludge with ZSM-5. 


\begin{tabular}{|l|c|c|c|c|}
\hline (mole) & H/C & O/C & N/C & S/C \\
\hline Oilfield-S No catalyst & 1.67 & 0.0131 & 0.0044 & 0.0066 \\
\hline Oilfield-S/Oilfield-S Ash/One Stage & 1.86 & 0.0038 & 0.0041 & 0.0059 \\
\hline Oilfield-S/Oil tank-S Ash/One Stage & 1.81 & 0.0039 & 0.0031 & 0.0058 \\
\hline Oil tank-S/No catalyst & 1.68 & 0.0998 & 0.0040 & 0.0071 \\
\hline Oil tank-S/Oilfield-S Ash/One Stage & 1.89 & 0.0063 & 0.0050 & 0.0072 \\
\hline Oil tank-S/Oil tank-S Ash/One Stage & 1.83 & 0.0051 & 0.0034 & 0.0069 \\
\hline
\end{tabular}

Table 5: Mole $\mathrm{H} / \mathrm{C}, \mathrm{O} / \mathrm{C}, \mathrm{S} / \mathrm{C}$ and N/C ratios of the oil products from the one stage catalytic pyrolysis of the oil sludge with the oil sludge ash.

far higher than those from the catalytic pyrolysis(0.75 8.25 wt\%). It is shown that the catalytic pyrolysis prevented coke formation more during the oil recovery than no catalyst case.

Table 5 shows the mole H/C, O/C, N/C, and S/C ratios of a part of the oil products. In both oil field sludge and oil tank sludge cases, the mole $\mathrm{H} / \mathrm{C}$ ratio of the oil product was increased from around 1.67 (no catalyst) to more than 1.8 (one stage pyrolysis with the oil field or oil tank sludge ash). The mole $\mathrm{O} / \mathrm{C}$ ratio decreased due to the vaporization of the water and halogenated metal containing oxygen. Therefore, the presence of oil sludge ash plays an important role in increasing the mole $\mathrm{H} / \mathrm{C}$ ratio and decreasing the mole $\mathrm{O} / \mathrm{C}$ ratio of the oil product. However, the mole $\mathrm{S} / \mathrm{C}$ and N/C ratios were not affected regularly.

\section{FT-IR analysis results}

The IR spectroscopy was used widely for evaluation of possible interaction and bonding mechanism of oil products. For this part of the study, the raw oil sludge and the oil products after the pyrolysis process of oil sludge with and without the catalyst of the oil sludge ash are analyzed by employing the FT-IR analysis. The liquid and solid samples were prepared by using the cast film and pressed-pellet method, respectively. The infrared spectra of the oil product with and without catalysts, and the raw oil sludge were compared in Figures 8 and 9. For brevity, only the oil products from the one stage pyrolysis with the catalyst of the oil sludge ash are provided.

The major vibration frequencies of the oil products are associated with the alkyl C-H modes of vibrations, such as $-\mathrm{CH}_{2}, \mathrm{CH}_{3}$ group. One would expect that the relative concentration of $-\mathrm{CH}_{2}$ and $\mathrm{CH}_{3}$ group are higher than others. In the case of oil sludge, whether the oil field sludge or the oil tank sludge, except for the dominant $\mathrm{C}-\mathrm{H}$ frequency peaks, the $\mathrm{O}-\mathrm{H}$ and $\mathrm{Si}-\mathrm{O}$ group which are formed by the interaction of oil, water and soil in the oil sludge, can be observed easily. However, the $\mathrm{O}-\mathrm{H}$ and $\mathrm{Si}-\mathrm{O}$ frequency peaks disappeared completely from the infrared spectra of the oil products. This is because that the oil products were separated from water and soil due to the pyrolysis process.

Comparing with the oil product without catalysts, as shown in Figures 8 and 9 , the intensity of $\mathrm{C}=\mathrm{C}$ stretch in aromatics decreased in the infrared spectra of the oil product with the oil sludge ash catalyst. Oppositely, the $\mathrm{C}=\mathrm{O}$ stretch in carbonyl/carboxylic became more prominent in the IR spectra of the oil product from the catalytic pyrolysis of the oil field sludge with the oil field sludge ash (Figure 8-a). These finding are in agreement with the result of [1], who pointed that this trend shows the effect of the dehydrogenation reaction with ketone and olefins formation during the pyrolysis of oil (Table 6).

\section{NMR analysis and average structural parameter}

In the NMR analysis, the oil products were dissolved in deuteriatedchloroform, and analyzed by the ${ }^{1} \mathrm{H}$ NMR and ${ }^{13} \mathrm{C}$ NMR spectroscopy. The average structural parameters of oil products were calculated by combining the results of the ${ }^{1} \mathrm{H}$ NMR spectra, ${ }^{13} \mathrm{C}$ NMR spectra with

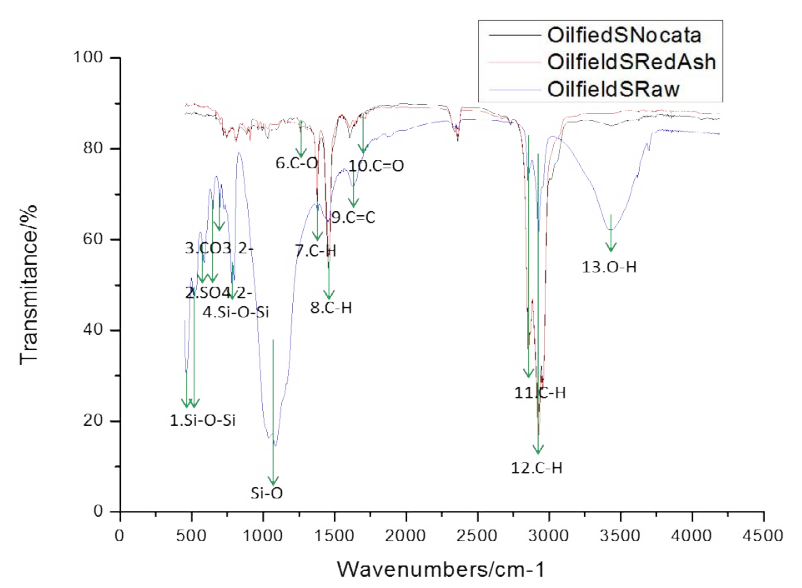

Figure 8: FT-IR spectra of the raw oil field sludge, the oil products from the one stage pyrolysis of the oil field sludge with and without the catalyst of the oil field sludge ash.

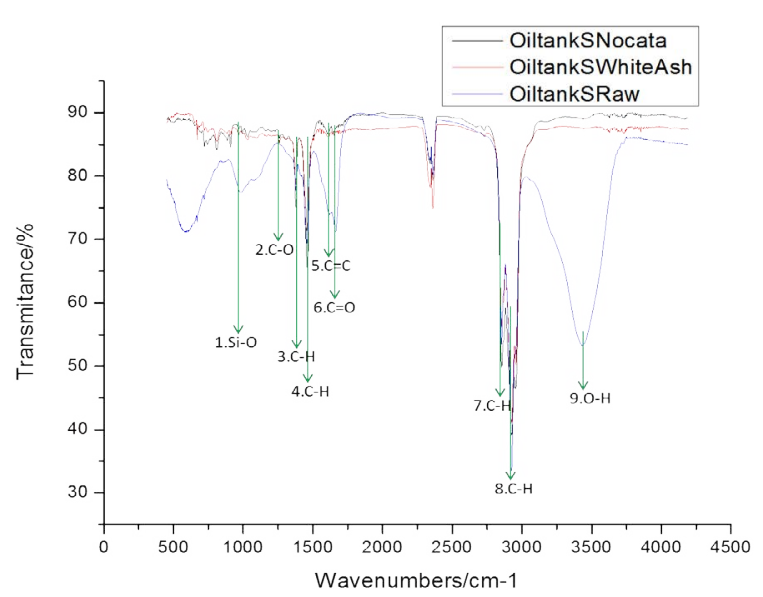

Figure 9: FT-IR spectra of the raw oil tank sludge, the oil products from the one stage pyrolysis of the oil tank sludge with and without the catalyst of the oil tank sludge ash.

\begin{tabular}{|l|c|c|}
\hline Modes of vibration & Frequency range & $\begin{array}{c}\text { Peak centered } \\
\text { at(cm-1) }\end{array}$ \\
\hline $\mathrm{Si}-\mathrm{O}-\mathrm{Si}$ bend & $540-400$ & 516 \\
\hline $\mathrm{SO}_{4}$ 2- bend & $680-580$ & $647 / 586$ \\
\hline $\mathrm{CO}_{3}$ 2- bend & $750-680$ & 694 \\
\hline $\mathrm{Si}-\mathrm{O}-\mathrm{Si}$ stretch & $800-600$ & 796 \\
\hline $\mathrm{Si}-\mathrm{O}$ stretch & $1100-970$ & $1037 / 981$ \\
\hline $\mathrm{C}-\mathrm{O}$ stretch & $1260-1250$ & 1259 \\
\hline $\mathrm{C}-\mathrm{H}$ symmetric deform in $\mathrm{CH}_{3}$ & $1385-1365$ & 1376 \\
\hline $\mathrm{C}-\mathrm{H}$ asymmetric deform in $\mathrm{CH}_{2}$ and & $1490-1430$ & 1457 \\
\hline $\mathrm{CH}$ & $1642-1547$ & 1604 \\
\hline $\mathrm{C}=\mathrm{C}$ stretch in aromatics & $1752-1640$ & $1716 / 1652$ \\
\hline $\mathrm{C}=\mathrm{O}$ stretch in carbonyl/carboxylic & $2863-2843$ & 2854 \\
\hline $\mathrm{C}-\mathrm{H}$ out-of-phase stretch in $\mathrm{CH}_{2}$ & $2936-2916$ & 2925 \\
\hline $\mathrm{C}-\mathrm{H}$ in-phase stretch in $\mathrm{CH}_{2}$ & $3630-3330$ & $3629 / 3428$ \\
\hline $\mathrm{O}-\mathrm{H}$ stretch & & \\
\hline
\end{tabular}

Table 6: Major modes in the IR of the oil product and the raw oil sludge. 
elemental analysis. The equations and parameters are listed in Table 7. It should be pointed out that the Brown-Ladner method is established under two assumed conditions: (1) Hs/Cs $\approx 2$, where Hs is the number of saturated hydrogen, Cs is the number of saturated carbon; (2) There is no other elements but only $\mathrm{C}$ and $\mathrm{H}$ exits in the oil product. According to the results of NMR analysis and the elemental analysis, the $\mathrm{Hs} / \mathrm{Cs}$ of the tested oil products in this study are in the range of $2.12 \sim 1.87$. And the weight percentages of $\mathrm{C}+\mathrm{H}$ of the tested oil products are higher than $96.5 \%$. Therefore, the actual situation of the oil products is generally in line with the two assumed conditions above.

Six groups of average structural parameter of oil products $(\mathrm{A} \sim \mathrm{F})$ were calculated, and presented in Figure 10 and Table 8. Figure 10 shows the ratios of the aliphatic carbon, the naphthenic carbon, and the aromatic carbon of the oil products. The main part of the carbon in all the oil samples is the aliphatic carbon. This result agrees with the result of FT-IR. Due to the hydrogenation of the aromatics and the presence of catalyst, the ratio of the aliphatic carbon of the oil sample increased from $65 \%$ (in A and D) to higher than $77 \%$ (in B, C, E and F). This increase is especially strong in the case with the oil field sludge ash, which might owe to the high $\mathrm{Ni}$ content of the oil field sludge and its ash. As known, the $\mathrm{Ni} / \mathrm{SiO}_{2}$ catalyst was widely used for hydrogenation of heavy oil and vacuum residuum. Although, in this experiment, no extra hydrogen was added to the reactor, and the presence of the paraffinic structure in the raw oil sludge provided a source of hydrogen

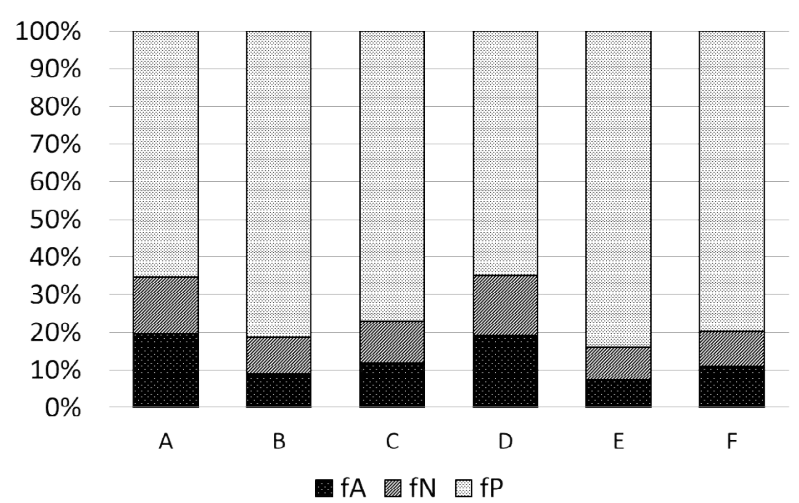

Figure 10: Ratio of aliphatic, naphthenic, and aromatic carbon obtained from the NMR spectra of the oil products from the one stage pyrolysis of the oil sludge with and without the catalyst of the oil sludge ash. in the hydrogenation. Moreover, the decarburization, which was presented by formation of coke, during the pyrolysis process, can also reduce the ratio of the naphthenic carbon and the aromatic carbon in the oil products.

The number of aromatic ring, naphthenic ring (RA and RN), and the average chain length of aliphatic chain or side chain $(\mathrm{L})$ shown in Table 8 can reflect the average molecular structure of the oil product visually. Each molecule of sample A and B contain about three aromatic rings and two and a half naphthenic rings in average. After the catalytic pyrolysis with the oil field sludge ash and the oil tank sludge ash, the number went down to $0.8 \sim 1.6$ and 1.5 1.9, respectively. This decrease can be explained by the hydrogenation and ring-open of naphthenic hydrocarbon during the catalytic pyrolysis reaction. As to the average chain length of the oil product, the reason of the decrease from the no catalyst cases (A and B) to the cases over the oil field sludge ash (B and E) might be attributed to the de-methylation of alkanes. However, this explanation is not suitable for the cases over the oil tank sludge ash ( $\mathrm{C}$ and $\mathrm{F})$. The $\mathrm{L}$ was calculated based on the value of $\mathrm{H} \gamma$ and $\mathrm{Cs}$, and this calculation method ignored the $-\mathrm{CH}_{3}$ on $\alpha$ and $\beta$ position. The simplification might lead to an unstable result or a mistake.

\section{Fuel characteristics of the blended fuels of oil products with diesel}

Several previous studies have shown that the characteristics of pyrolytic oil products of oil sludge are similar to commercial diesel. However, it still contains amount of impurities and vacuum residues. In this part, the oil products from the one stage pyrolysis process of the oil field sludge with the oil field sludge ash (B), and from the one stage pyrolysis process of the oil tank sludge with the oil tank sludge ash $(\mathrm{F})$ were mixed with commercial diesel (the diesel standard) by one-to-five and one-to-ten volume ratio. We chose these two oil products in the

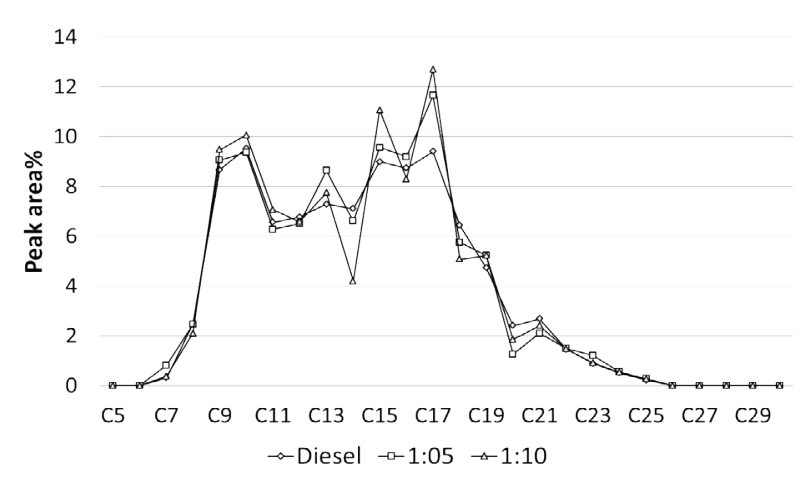

Figure 11: Carbon distillation of the mixed fuels of diesel with the oil product from the pyrolysis of the oil field sludge with the oil field sludge ash. 


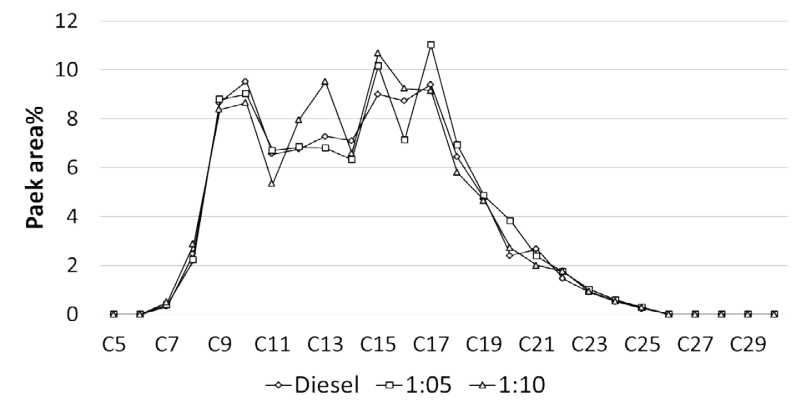

Figure 12: Carbon distillation of the mixed fuels of diesel with the oil product from the pyrolysis of the oil tank sludge with the oil tank sludge ash.

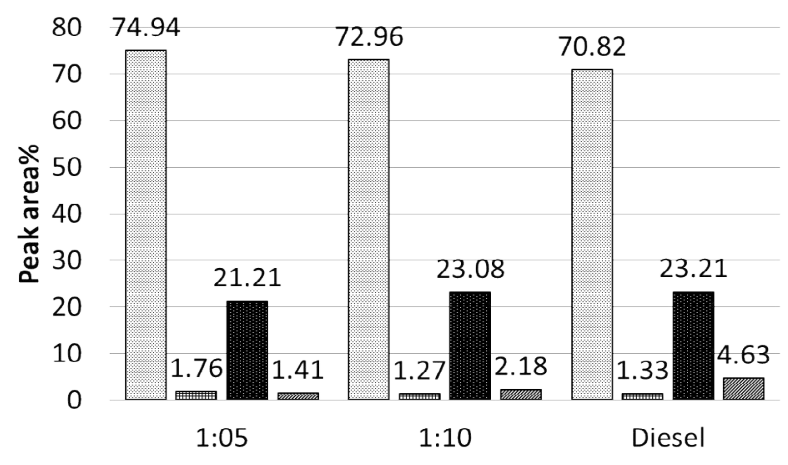

$\square$ Saturate Olefine Aromatic 圆 Nonhydrocarbon

Figure 13: Chemical composition of the mixed fuels of diesel with the oil product from the pyrolysis of the oil field sludge with the oil field sludge ash.

view of commercial angle for two reasons: (1) The presence of oil sludge ash in the one stage pyrolysis did improve the yield and quality of the oil product; (2) The source of oil sludge ash is the pyrolysis residue of oil sludge, which means that the oil sludge ash catalyst can be produced as long as the pyrolysis process of oil sludge will be continued.

The mixtures were filtered using $0.8 \mu \mathrm{m}(47 \mathrm{~mm})$ pore size filter film to remove the insoluble impurities and vacuum residues. The kinematic viscosity, the density, the higher heating value (HHV) and the catene index of the soluble material are summarized in Table 9. All of the mixed liquids have higher HHV than the commercial diesel. For the same oil product, HHV of the fuel with the mixing ratio of 1: 10 is higher than that of $1: 5$. We can expect that the mixing ratio of 1 : 10 can support the burning and heat release of the mixed fuel better. Moreover, the catena index, which reflects the ignition characteristics of a diesel range fuel, of these mixed fuels also shows the same tendency with HHV. For further analysis of the chemical components of these mixed fuels, the fuel samples were measured by using the GC-MS. The chromatograms of the samples from GC-MS analysis were compared with the results of GC-FID, and the main identified components are

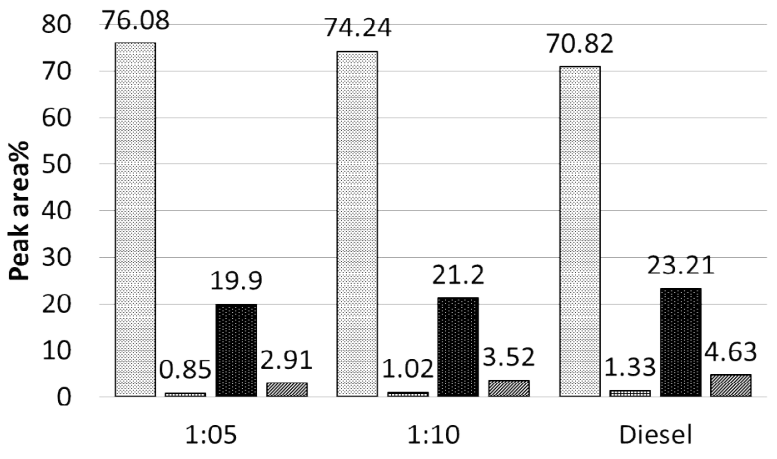

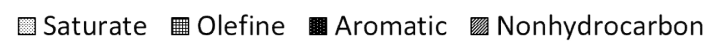

Figure 14: Chemical composition of the mixed fuels of diesel with the oil product from the pyrolysis of the oil tank sludge with the oil tank sludge ash.

\begin{tabular}{|c|c|c|c|c|c|c|}
\hline & $\mathbf{A}^{*}$ & $\mathbf{B}^{*}$ & $\mathbf{C}^{*}$ & $\mathbf{D}^{*}$ & $\mathbf{E}^{*}$ & $\mathbf{F}^{*}$ \\
\hline $\mathrm{C}(\mathrm{Wt} \%)$ & 84.69 & 84.7 & 84.0 & 84.9 & 83.9 & 84.51 \\
\hline $\mathrm{H}(\mathrm{Wt} \%)$ & 11.81 & 13.11 & 12.67 & 11.87 & 13.21 & 12.91 \\
\hline $\mathrm{S}(\mathrm{Wt} \%)$ & 1.48 & 1.35 & 1.33 & 1.6 & 1.63 & 1.56 \\
\hline $\mathrm{N}(\mathrm{Wt} \%)$ & 0.44 & 0.41 & 0.31 & 0.4 & 0.49 & 0.34 \\
\hline $\begin{array}{c}\text { O (a) } \\
(\mathrm{Wt} \%)\end{array}$ & 1.48 & 0.43 & 0.44 & 1.13 & 0.7 & 0.58 \\
\hline $\mathrm{RT}$ & 5.6 & 2.8 & 3.5 & 5.7 & 2.3 & 3.1 \\
\hline $\mathrm{RA}$ & 3.0 & 1.1 & 1.6 & 2.9 & 0.8 & 1.4 \\
\hline $\mathrm{RN}$ & 2.6 & 1.7 & 1.9 & 2.8 & 1.5 & 1.7 \\
\hline $\mathrm{L}$ & 6.0 & 5.8 & 6.1 & 5.6 & 5.5 & 5.8 \\
\hline
\end{tabular}

A: Oil product from the no catalyst pyrolysis of the oil field sludge;

$\mathrm{B}$ : Oil product from the one stage pyrolysis of the oil field sludge with the oil field sludge ash;

C: Oil product from the one stage pyrolysis of the oil field sludge with the oil tank sludge ash;

D: Oil product from the no catalyst pyrolysis of the oil tank sludge;

$\mathrm{E}$ : Oil product from the one stage pyrolysis of the oil tank sludge with the oil field sludge ash;

F: Oil product from the one stage pyrolysis of the oil tank sludge with the oil tank sludge ash.

Table 8: Elemental analysis results and distribution of ring number of the oil products from the one stage pyrolysis of the oil sludge with and without the catalyst of the oil sludge ash.

\begin{tabular}{|c|c|c|c|c|}
\hline & $\begin{array}{l}\text { Kinematic } \\
\text { viscosity } \\
\text { (40degC) }\end{array}$ & $\begin{array}{c}\text { Density } \\
\left(20^{\circ} \mathrm{C}-\mathrm{g} / \mathrm{cm} 3\right)\end{array}$ & $\begin{array}{c}\text { Heating } \\
\text { value(HHV) } \\
(\mathrm{MJ} / \mathrm{kg})\end{array}$ & Cetane index \\
\hline \multicolumn{5}{|c|}{$\begin{array}{l}\text { Oil product(oil } \\
\text { field-S/oil } \\
\text { field-S ash/one } \\
\text { stage) : Diesel }\end{array}$} \\
\hline $1: 5$ & 2.53 & 0.819 & 45.7 & 38.22 \\
\hline $1: 10$ & 2.52 & 0.812 & 46.1 & 38.51 \\
\hline \multicolumn{5}{|c|}{$\begin{array}{l}\text { Oil product(oil } \\
\text { tank-S/oil } \\
\text { tank-S ash/one } \\
\text { stage) : Diesel }\end{array}$} \\
\hline $1: 5$ & 2.54 & 0.813 & 45.3 & 37.53 \\
\hline $1: 10$ & 2.50 & 0.810 & 45.8 & 37.58 \\
\hline $\begin{array}{l}\text { Diesel } \\
\text { standard }\end{array}$ & 2.49 & 0.809 & 45.2 & 35.44 \\
\hline
\end{tabular}

Table 9: Kinematic viscosity, density, heating value and cetane index of the mixed fuels and diesel standard. 
Page 11 of 12

\begin{tabular}{|c|c|c|c|c|c|c|c|}
\hline \multirow{3}{*}{$\begin{array}{c}\text { No. } \\
\text { Saturate }\end{array}$} & \multirow{2}{*}{\multicolumn{2}{|c|}{ R.T.(min) Compounds }} & \multicolumn{2}{|c|}{ Area (\%) } & $\mathrm{B}^{*}$ :diesel & \multicolumn{2}{|c|}{$\mathrm{F}^{*}$ :diesel } \\
\hline & & & \multirow[t]{2}{*}{ Diesel } & \multirow[t]{2}{*}{$1: 5(v / v)$} & \multirow[t]{2}{*}{$1: 10(v / v)$} & \multirow[t]{2}{*}{$1: 5(v / v)$} & \multirow[t]{2}{*}{$1: 10(v / v)$} \\
\hline & & & & & & & \\
\hline 1 & 35.98 & Hexadecane & 4.62 & 4.33 & 4.6 & 4.8 & 4.36 \\
\hline 2 & 39.66 & Heptadecane & 4.42 & 4.32 & 4.32 & 4.6 & 4.36 \\
\hline 3 & 32.09 & Pentadecane & 4.41 & 4.46 & 4.44 & 4.66 & 4.49 \\
\hline 4 & 43.13 & Octadecane & 3.75 & 3.99 & 3.89 & 3.16 & 3.77 \\
\hline 5 & 46.43 & Nonadecane & 2.99 & 2.95 & 2.97 & 2.76 & 2.97 \\
\hline 6 & 27.97 & Tetradecane & 2.94 & 2.86 & 2.85 & 2.92 & 3.03 \\
\hline 7 & 49.57 & Eicosane & 2.85 & 2.44 & 2.56 & 2.1 & 2.51 \\
\hline 8 & 52.57 & Heneicosane & 1.96 & 1.97 & 1.95 & 1.6 & 1.99 \\
\hline 9 & 23.65 & Tridecane & 1.8 & 2 & 1.74 & 1.82 & 1.85 \\
\hline 10 & 14.57 & Undecane & 1.73 & 1.73 & 1.74 & 1.77 & 1.74 \\
\hline 11 & 19.14 & Dodecane & 1.61 & 1.82 & 1.67 & 1.6 & 1.8 \\
\hline 12 & 10.11 & Decane & 1.32 & 1.36 & 1.38 & 1.37 & 1.35 \\
\hline 13 & 6.04 & Nonane & 1.22 & 1.15 & 1.2 & 1.22 & 1.21 \\
\hline 14 & 37.66 & Hexadecane, 3-methyl- & 1.2 & 1.22 & 1.2 & 1.24 & 1.21 \\
\hline 15 & 30.47 & Tridecane, 3-methyl- & 1.29 & 1.25 & 1.27 & 1.31 & 1.27 \\
\hline 16 & 43.36 & $\begin{array}{c}\text { Hexadecane, } \\
2,6,10,14 \text {-tetramethyl- }\end{array}$ & 1.31 & 1.58 & 1.52 & 1.4 & 1.31 \\
\hline 17 & - & Docosane & 1.45 & 1.49 & 1.46 & - & - \\
\hline 18 & - & $\begin{array}{c}\text { Pentadecane, } \\
2,6,10,14 \text {-tetramethyl }\end{array}$ & - & - & - & 1.06 & 1.2 \\
\hline \multicolumn{8}{|l|}{ Aromatic } \\
\hline 19 & 8.49 & Benzene, 1,2,3-trimethyl- & 1.53 & 1.32 & 1.43 & 1.32 & 1.31 \\
\hline 20 & 5.36 & p-Xylene & 1.07 & 1.08 & 1.1 & 1.04 & 1.07 \\
\hline \multicolumn{8}{|c|}{ Nonhydrocarbon } \\
\hline 21 & - & $\begin{array}{c}\text { Octadecane, } \\
\text { 1-(ethenyloxy)- }\end{array}$ & 0.27 & - & 0.12 & - & 0.12 \\
\hline 22 & - & $\begin{array}{l}\text { Oxirane, [(dodecyloxy) } \\
\text { methyl]- }\end{array}$ & - & 0.49 & - & - & - \\
\hline 23 & - & Ethanol, 2-(dodecyloxy)- & 0.33 & - & - & 0.28 & \\
\hline
\end{tabular}

Table 10: Main components identified by GC-MS for the mixed fuels and diesel standard.

From the carbon distillation of all the mixed fuels and the commercial diesel (Figures 11 and 12), it can be seen that the range of carbon distillation of these mixed fuels $\left(\mathrm{C}_{7} \sim \mathrm{C}_{26}\right)$ is identical with diesel. However, the distillation curve of both oil product-diesel mixtures with the mixing ratio of 1:10 present a strong fluctuation in the range of $\mathrm{C}_{12} \sim \mathrm{C}_{17}$. Thus it can be seen that the mixture of the oil product and diesel maybe not a simple mixing of chemical components. Some unknown interactions between the chemical components in the oil product and the diesel may happen, which would affect the detection results of GC-MS

In Figures 13 and 14, the mixed fuels and diesel are divided into saturates: alkane and cycloalkane; olefin; Aromatics; and nonhydrocarbon: resin and heterocyclic. From both Figures 13 and 14, we can see that the saturate content of the mixed fuel increased with the increase of the oil product proportion. On the other hand, the compositions of aromatic and non-hydrocarbon decreased with the increase of the oil product proportion. Combining with HHV and cetane index results above, one can expect that the adding of pyrolytic oil product improved the quality of diesel oil to same extent.

\section{Conclusions}

First, this experimental study indicates that the oil fraction can be separated from water and soil by the pyrolysis process of oil sludge with and without catalysts. On the whole, the yield of the oil products of the one stage pyrolysis is higher than that of the two stage case, whether the feedstock is the oil field sludge or the oil tank sludge. The highest oil product yield is obtained in the one stage pyrolysis of the oil field sludge and also the oil tank sludge with the oil field sludge ash. This can be partially attributed to the nature of the presence of Fe element and S element in the oil field sludge ash.

Second, the distillation characteristic curves of the oil products show that the boiling range of all the oil products produced from the catalytic pyrolysis are between the boiling range of the no catalyst oil product and diesel standard, though there is no obvious difference between the one stage pyrolysis and the two stage pyrolysis processes in the boiling range. In the catalytic pyrolysis process of the oil field sludge, all of the catalysts can improve the quality of the oil products by decreasing their boiling point range. However, for the distillation characteristics of the oil products from the catalytic pyrolysis of the oil tank sludge, it was found that neither the type of catalysts nor the pyrolysis method affected the boiling range of the oil product significantly, except for the oil product with the catalyst of the oil tank sludge ash and ZSM-5.

Third, according to the results of NMR and FT-IR analysis, the main part of the carbon in the oil product from the pyrolysis of the oil sludge with the oil sludge ash is aliphatic carbon. The total ring number 
of the oil products decreased owing to the hydrogenation and ringopen of naphthenic hydrocarbon during the catalytic pyrolysis process.

Last but not least, the highest HHV and cetane index can be obtained, when the oil product from the one pyrolysis process of the oil field sludge with the oil field sludge ash was mixed with diesel with the mixing ratio of $1: 10$. The range of carbon distillation of all the mixed fuels $(\mathrm{C} 7 \sim \mathrm{C} 26)$ was identical with diesel standard. The saturate contents of mixed fuel increased with the increase of the oil product proportion. Combining with HHV and cetane index results, we can expect that addition of the pyrolytic oil product will improve the quality of diesel oil to some extent.

\section{References}

1. Ma Z, Gao N, Xie L, Li A (2014) Study of the fast pyrolysis of oilfield sludge with solid heat carrier in a rotary kiln for pyrolytic oil production. Journal of Analytical and Applied Pyrolysis 105: 183-190.

2. Wenying $Z$, Jingchun $T$, Fei W, Daming $L$ (2012) Pollution of oil sludge and its disposal techniques in china and abroad. Petrochemical Industry Application.

3. Jin Y, Zheng X, Chu X, Chi Y, Yan J, et al. (2012) Oil recovery from oil sludge through combined ultrasound and thermochemical cleaning treatment. Ind Eng Chem Res 51: 9213-9217.

4. Yeung $P$, Johnson R, Acharya S (1993) An improved procedure for determining oil content in wet soil samples. ASTM Special Technical Publication 1221: 11.

5. Ilias AM (1993) Fuel isolation, identification and quantitation from soils.ASTM Special Technical Publication 1221: 15.

6. Wang Z, Guo Q, Liu X, Cao C (2007) Low temperature pyrolysis characteristics of oil sludge under various heating conditions. Energy Fuels 21: 957-962.

7. Sankaran S, Pandey S, Sumathy K (2008) Experimental investigation on waste heat recovery by refinery oil sludge incineration using fluidised-bed technique. Journal of Environmental Science and Health, Part A: Toxic/Hazardous Substances and Environmental Engineering 33: 829-845.

8. Yu Ling Wei, Chin Hua Wu (2012) PAH emissions from the fluidized-bed incineration of an industrial sludge. Journal of the Air \& Waste Management Association 47: 953-960.

9. Schmidt $\mathrm{H}$, Kaminsky W (2001) Pyrolysis of oil sludge in a fluidized bed reactor. Chemosphere 45: 285-290.
10. Shie J, Chang C, Lin J, Wu C, Lee D (200) Resources recovery of oil sludge by pyrolysis: kinetics study J Chem Technol Biotechnol 75: 443-450.

11. Chang C, Shie J, Lin J, Wu C, Lee D, et al. (2000) Major products obtained from the pyrolysis of oil sludge. Energy Fuels 14: 1176-1183.

12. Shie J, Chang C, Lin J, Lee D, Wu C (2001) Use of inexpensive additives in pyrolysis of oil sludge. Energy Fuels 16: 102-108.

13. Shie J, Lin J, Lee D, Wu C (2003) Pyrolysis of oil sludge with additives of sodium and potassium compounds. Resources, Conservation and Recycling 39: $51-64$.

14. Shie JL, Chang CY, Lin JP (2004) Oxidative thermal treatment of oil sludge at low heating rates. Energy \& fuels: An American Chemical Society journal 18 : 1272-1281.

15. Shie J, Lin J, Chang C, Shih S, Lee D, et al. (2004) Pyrolysis of oil sludge with additives of catalytic solid wastes. Journal of Analytical and Applied Pyrolysis 71: 695-707.

16. Chang C, Shie J, Lin J, Wu C, Lee D, et al. (2000) Major products obtained from the pyrolysis of oil sludge. Energy Fuels 14: 1176-1183.

17. Tomita A, Watanabe Y, Takarada T, Ohtsuka Y, Tamai Y (1985) Nickelcatalysed gasification of brown coal in a fluidized bed reactor at atmospheric pressure. Fuel 64: 795-800.

18. Siddiqui $M N(2010)$ Catalytic pyrolysis of Arab heavy residue and effects on the chemistry of asphaltene. Journal of Analytical and Applied Pyrolysis 89: 278-285.

19. Brown JK, Landner WR (1960) A study of the hydrogen distribution in coallike materials by high-resolution nuclear magnetic resonance spectroscopy 1. A comparison with infra-red measurement and the conversion to carbon structure. Fuel 39: 87-96

20. Williams RB (1958) Characterization of hydrocarbons in petroleum by nuclear magnetic resonance. Symposium on composition of Petroleum Oils. ASTM, Spec Tech Publ 224.

21. Gonçalves MLA, Ribeiro DA, Mota DAPD, Teixeira AMRF, Teixeira MAG (2006) Investigation of petroleum medium fractions and distillation residues from brazilian crude oils by thermogravimetry. Fuel 85: 1151-1155.

22. Mondragon F, Ouchi K (1984) New method for obtaining the distillation curves of petroleum products and coal-derived liquids using a small amount of sample. Fuel 63: 61-65.

23. Kotanigawa T, Yamamoto M, Sasaki M, Wang N, Nagaishi H, et al. (1997) Active site of iron-based catalyst in coal liquefaction. Energy Fuels 11: 190-193. 